\title{
OPEN Author Correction: Aberrant DNA methylation of miRNAs in Fuchs endothelial corneal dystrophy
}

\section{Peipei Pan, Daniel J. Weisenberger, Siyu Zheng, Marie Wolf, David G. Hwang, Jennifer R. Rose-Nussbaumer, Ula V. Jurkunas \& Matilda F. Chan}

Correction to: Scientific Reports https://doi.org/10.1038/s41598-019-52727-z, published online 08 November 2019

The Acknowledgements section in this Article is incomplete.

"We thank Emily Khuc and Selene M. Clay for collecting patients samples for the original genome-wide DNA methylation assay."

should read:

"We thank Emily Khuc and Selene M. Clay for collecting patients samples for the original genome-wide DNA methylation assay. This study was supported by funds from a Research to Prevent Blindness (RPB) Physician-Scientist Award (to MFC, https://www.rpbusa.org/rpb/), an RPB Unrestricted Grant (to UCSF Department of Ophthalmology, https://www.rpbusa.org/rpb/), the National Institutes of Health (R01 EY022739 to MFC, NIH-NEI EY002162 - Core Grant for Vision Research, NIH/NCRR UCSF-CTSI Grant Number UL1 RR024131 to MFC), and That Man May See (http://thatmanmaysee.org/)."

\begin{abstract}
(1) Open Access This article is licensed under a Creative Commons Attribution 4.0 International License, which permits use, sharing, adaptation, distribution and reproduction in any medium or format, as long as you give appropriate credit to the original author(s) and the source, provide a link to the Creative Commons license, and indicate if changes were made. The images or other third party material in this article are included in the article's Creative Commons license, unless indicated otherwise in a credit line to the material. If material is not included in the article's Creative Commons license and your intended use is not permitted by statutory regulation or exceeds the permitted use, you will need to obtain permission directly from the copyright holder. To view a copy of this license, visit http://creativecommons.org/licenses/by/4.0/.
\end{abstract}

(C) The Author(s) 2020 